\title{
Empirical Test on Building up Competitiveness Appraisal System of Joint Stock Commercial Banks in China
}

\author{
Yanjuan Cui ${ }^{1,2}$ \\ ${ }^{1}$ School of Finance, Dongbei University of Finance and Economics, Dalian, China \\ ${ }^{2}$ School of Management, Dalian Polytechnic University, Dalian, China \\ Correspondence: Yanjuan Cui, School of Management, Dalian Polytechnic University, 1 Qing Gong Yuan, Gan \\ Jing Zi, Dalian, 116034, China. Tel: 86-411-8632-3622. E-mail: tsuiyanjuan@163.com
}

\author{
Received: June 11, $2012 \quad$ Accepted: July 11, $2012 \quad$ Online Published: September 1, 2012 \\ doi:10.5539/ijef.v4n9p149 URL: http://dx.doi.org/10.5539/ijef.v4n9p149
}

\begin{abstract}
Joint stock commercial banks are very important for a nation's financial development and operation of the banking sectors. Whether the competitiveness can be appraised objectively or not is very significant for financial sector healthy development and financial system deepening. Based on describing the research status, the definition of joint stock commercial banks competitiveness is making sure, then the appraisal system is built up, at last empirical test and analysis are made with the samples of 11 joint stock commercial banks in China. The conclusion is that the state-owned joint stock commercial banks have comparative competitiveness. And the non state-owned banks still show the potential development, especially China Merchants Bank. All the joint stock commercial banks have good development environment, especially the state-owned banks. Some measurement can be taken to enhance their competitiveness gradually.
\end{abstract}

Keywords: joint stock commercial banks, competitiveness, appraisal system, empirical test

\section{Introduction}

In China, joint stock commercial banks have been the important and indispensable component of the banking industry and national economy development since Bank of Communication (BOCOM) rescue to set up in July 24, 1986. According to the statistics of China Banking Regulatory Commission (CBRC), the total assets of whole joint stock commercial banks in China is 14.9 trillion Yuan in the year 2010, increasing by $26.1 \%$. Commercial banks perform several valuable services to sectors of the economy (Marcia M.C. \& Hassan T., 2004). The development of joint stock commercial banks not only promote Chinese finance development, but also improve the bank's operating efficiency. Therefore, it is very significant to analyze their competitiveness.

The early competitiveness is from "diamond model" (Michael E. P., 1980, 1985, 1990). And now the bank competitiveness studies are focus on indicator system and appraisal model. First, it is the standard of the financial system competitiveness established by the World Economic Forum (WEF) and International Institute for Management Development (IMD), which utilizes capital, capital efficiency, security markets and financial services efficiency to measure a country's overall competitiveness of the financial industry. Second, the journal of 'The banker' makes an evaluation of the world's Top 1,000 banks. They use the main indices of core capital, assets, capital assets ratio, profits and operating conditions. That biggest advantage is to reflect the current condition of the banks assets and profitability. Third, there are some evaluation methods of international credit rating companies. For example, CAMELS system is focusing on financial indicators, while Moody's Investors Service and Standard \& Poor's evaluate credit rating of the international companies and commercial banks every year. Besides those, bank concentration is usually used as a proxy for competition in many researchers (Cetorelli, 1999), but some argument disagree, there are some measurement problems and misleading inferences (Claessens and Laeven, 2004). And generally, others studies are based on those. Some indexes are usually used to measure the performance, which is also one aspect of commercial bank competitiveness, e.g. bank profitability and margins (Naceur, S. B. and Goaied, M., 2003; Beckmann R., 2007; Toni U., 2008 et al), return on assets, total liabilities/total assets, total liabilities/total assets (Khrawish H. A., 2011), those indexes are also used to measure bank's competitive conditions (Cengiz E., Omar M., Bora A. and Bruno S., 2012). All those researches have their own advantages, however, when actually implying, they may be have no effect with some specific bank or can't reflect the characteristics of the China's commercial banks. So the appropriate evaluation system should be 
building up to appraise the competitiveness of joint stock commercial banks.

In China, the researches on bank competitiveness are empirical test. For example, JIAO Jinpu (2001), senior economist of People's Bank of China, gave the banking appraisal system and use it to analyze the reality competitiveness of the fourth state-owned commercial banks. That result is the most important reference for the domestic research. LI Yuanxu (2000) did the comparison research on the competitiveness between the national state-owned commercial banks and foreign banks from the three aspects of economic benefit, security capacity and operational capacity. HUANG Lan and SHEN Gensheng (2002) put forward commercial banks appraisal indices system form the elements of resource, capacity and environment. YAO Zheng and SHAO Qinhua (2005) discussed how to choose the competitiveness appraisal indices and weight of commercial banks. SONG Wenchang (2007) used the unified indicator to analyze competitiveness of listed joint stock commercial banks. Others research such as YANG Jiacai(2008), LU Yuexiang and CAO Yongdong(2011) etc. The method used in those studies are analytic hierarchy process (AHP), factor analysis and comparative analysis etc. the result is obscure because of using expert subjective assessment in AHP method, or short of reasonable indicators system. Factor analysis has no those weakness, but there is lack of the inclusive factors analysis. It is strategic significance to appraise competitiveness of joint stock commercial banks objectively by relevant index system.

This paper researches 11 joint stock commercial banks competitiveness in China with factor analysis, in order to promote financial sector develop healthily and deepen the financial system with relevant strategy. The second section explains the main content of joint stock commercial banks competition, and then the appraisal system is built up. In the third section, 11 joint commercial banks are used as samples to test the system empirically with software SPSS 16.0, and the competitiveness sorting is given. The fourth section goes on illustrate the extracted common factors means, explain each factor score and sorting of the sample bank. The last is the main conclusion, that is, the joint stock commercial banks have good development environment, especially the state-owned banks. And they can take some measurement to enhance the competitiveness gradually.

\section{Main Contents and Appraisal Indictors System of Joint Stock Commercial Banks Competitiveness}

\subsection{Main Contents of Joint Stock Commercial Banks Competitiveness}

Competitiveness of joint stock commercial banks should have the general meaning of enterprises. Furthermore, it should be multi-level, dynamic and evolutionary development capabilities. So when analyzing the competitiveness, it would consider not only the natures of bank, which is the basic competitiveness, but also the core competitiveness and global economy, which is the international competitiveness.

The basic competitiveness of banks natures is efficiency, security and liquidity, which is determined by the characteristics of the banks itself. The core competitiveness mainly refers to those reflecting in operation process and comparison with the banks, which mainly refers to the ability of operating, innovation, human capital management, corporate governance and brand influence and etc. Under economy and finance globalization, the national and international developing environment and technical level are the main factors influencing international competitiveness, which can be explained specifically by macro economy environment, government policies and institutions, financial development environment and electronic degree and so on.

Thus the contents of joint stock commercial banks competitiveness can be expressed as: under the specific market economy, based on using and creating resources effectively, the commercial bank utilizes unique financial products, special geographic, popularity and other advantages to make themselves adapt the environment changes to satisfy consumers' needs more quickly, finely and safely than other competitors and to obtain benefits of competitive advantage, so that the sustainable competitiveness can be improved at last.

\subsection{Building up the Appraisal Indicators System of Joint Stock Competitiveness}

According to the main contents and level of joint stock commercial banks, and based on the scientific, systematic, operational and comparable principles, the appraisal indicators system of joint stock competitiveness can be built up. There are seven primary indicators: profitability, security, liquidity, operation ability, human capital, business innovation ability and corporate governance. And several secondary indicators are including in every primary indicator excluding the last one. Some indicators are quantitative and others are qualitative. When some indicator can belong to different primary indices, it should be determined by their intimacy degree to the influence factors.

There are four secondary indicators, return on total assets (ROTA), capital profit ratio (CPR), income profit margin (IPM) and cost to income ratio (CIR), to assess the profitability. ROTA is the indicator to reflect the relationship of asset efficiency and effect. The higher it is, the more efficient the bank's assets operate. CPR reflects asset's benefit. The higher the return on capital is, the less the risk of investors is. IPM is the ratio of bank's business operating income into bank profits. 
CIR is one of most important indicators to measure bank profitability. The lower it is, the stronger the bank's ability to earn income is. According to CBRC, it is not more than $45 \%$.

There are three indicators to measure the security. They are capital adequacy ratio (CAR), non performing assets ratio (NPAR) and provision coverage ratio (PCR). CAR is necessary ratio for banks and other financial institutions to ensure the normal operation and development. The larger it is the stronger ability against risk the bank has. NPAR is one of the most direct means to measure the risk of commercial banks. It is also used to determine whether the business strategy is correct or not, and determine the ability of banks to prevent the actual risk. The lower it is, the stronger the bank's competitiveness is. PCR is to measure the adequacy of loan losses reserve of commercial bank. The lower it is, the little and the loss is.

Liquidity can be appraisal by the two indicators of liquidity ratio (LR) and loan to deposit ratio (LDR). LR is one of important indicators to measure liquidity risk degree of commercial bank. The higher the ratio is, the smaller the liquidity risk is, and the lower the profitability is. LDR is the ratio of total deposits to total loans. If considering from profitability, the higher and the better. However, if from the aspect of preventing risk, the lower the better. Currently, the ratio is limited to below $75 \%$.

There asset growth rate (AGR), growth rate of net profit (GRNP), deposit growth rate (DGR) and growth rate on lending (GRL) are in the primary indicator of operation ability. The higher the four indicators are, the stronger the bank competitiveness is.

Human capital is necessary for modern commercial banks to create value and realize the sustainable development. It can be measured with rate of college degree or above (RCD) and ratio of middle title or above (RMT). The two secondary indicators are reflecting the excellent quality of staff.

Both non interest income ratio (NIIR) and off balance sheet income ratio (OBSR) determine the business innovation ability. That is, they determine what financial products and services the commercial bank can provide to customers and to meet the market development.

Shareholding proportion of the controlling shareholder (SPCS) reflects the degree of ownership concentration to some extent. The controlling shareholder has the right to determine the financial and operating policies, so it can reflect whether the corporate governance structure is perfect or not.

\section{Empirical Analysis on Competitiveness of 11 Joint Stock Commercial Banks in China}

\subsection{Samples and Data Sources}

The sample in this paper includes both state-owned and non state-owned joint commercial bank in China. Considering the assets, lending and the possibility of obtaining data, we choose 11 banks as study samples, they are Industrial and Commercial Bank of China Limited (ICBC), Bank of China (BOC), China construction bank (CCB), Bank of Communication (BOCOM), China Merchants Bank (CMB), China Mingsheng Banking Co., Ltd (CMBC), Shanghai Pudong Development Bank (SPDB), Huaxia bank (HXB), Shezhen Development Bank (SDB), China Citic Bank (CITIC), China Industrial Bank, Co., Ltd (CIB).

All the data are from China Statistical Yearbook 2009 and 2010, financial statistics Yearbook 2009 and 2010, annual reports of the related banks, the People's Bank of China and CBRC. Then Factor analysis is conducted with the help of software SPSS16.0 based on the indices system.

\subsection{Empirical Test on Banks Competitiveness with Factor Analysis}

Make the original data dimensionless first, and then calculate the mean value and standard deviation for each processed data. All of the variables have higher correlation except AGR, DGR GRL. That means the common factors can be extracted from them. Using the software of SPSS16.0, Kaiser-Meyer-Olkin (KMO) value is 0.758, larger than 0.7. And Bartlett's test of sphericity is 210.731, the significant level is 0.000 . So the related coefficient matrix and the unit matrix are very different significantly. The two values show the indicator variables suitable for factor analysis. Both eigenvalue and variance contribution ratio (VCR) are calculated by SPSS 16.0, shown in Table 1. 
Table 1. Eigenvalue and VCR of factor analysis

\begin{tabular}{lccc}
\hline Common Factor & Eigenvalue & VCR (\%) & Accumulated VCR (\%) \\
\hline F1 & 6.986 & 38.813 & 38.813 \\
F2 & 4.281 & 23.786 & 62.599 \\
F3 & 2.120 & 11.776 & 74.375 \\
F4 & 1.561 & 8.672 & 83.047 \\
F5 & 1.048 & 5.823 & 88.870 \\
F6 & 0.760 & 4.221 & 93.091 \\
F7 & 0.632 & 3.514 & 96.604 \\
F8 & 0.391 & 2.174 & 98.778 \\
F9 & 0.142 & 0.787 & 99.565 \\
\hline
\end{tabular}

According to the principles of eigenvalue over 1 , the common factors can be extracted from the 18 indicators and also the number of common factors can be determined. From table 1, the total cumulative data rate of F1, F2, F3, $\mathrm{F} 4$ and F5 have reached $88.87 \%$. Cumulative rate of F1 is the largest among those, $38.813 \%$. The followings are F2, F3, F4 and F5 in turn, and the rate is $23.786 \%, 11.776 \%, 8.672 \%$ and $5.823 \%$ by each, which have been more than others. Furthermore, from the screen plot, which is also from SPSS16.0, there is a huge gap between those five factors and others. And the fold line is flatter at the sixth factor. Therefore, we selected the former five common factors to evaluate the joint stock commercial banks competitiveness.

Table 2. Rotated factor matrix after orthogonal rotation

\begin{tabular}{lccccc}
\hline \multicolumn{1}{c}{ Indicator } & $\mathrm{F} 1$ & $\mathrm{~F} 2$ & $\mathrm{~F} 3$ & $\mathrm{~F} 4$ & $\mathrm{~F} 5$ \\
\hline IPM & 0.950 & 0.087 & -0.222 & -0.064 & -0.089 \\
CPR & 0.937 & -0.008 & -0.205 & -0.067 & -0.165 \\
ROTA & 0.936 & 0.175 & -0.259 & 0.004 & -0.133 \\
GRNP & 0.784 & -0.161 & 0.123 & -0.286 & 0.469 \\
PCR & 0.740 & -0.196 & 0.347 & 0.454 & -0.047 \\
RMT & -0.106 & -0.287 & -0.020 & 0.858 & -0.211 \\
NIIR & -0.311 & 0.818 & 0.016 & -0.042 & 0.235 \\
NPAR & 0.090 & 0.683 & -0.312 & -0.558 & 0.143 \\
CAR & 0.324 & 0.664 & -0.508 & -0.139 & -0.007 \\
CIR & -0.107 & 0.031 & 0.868 & 0.076 & 0.204 \\
SPCS & 0.110 & 0.393 & -0.846 & -0.057 & 0.305 \\
RCD & -0.195 & -0.258 & 0.600 & 0.660 & 0.207 \\
LDR & -0.296 & -0.447 & 0.374 & 0.193 & 0.641 \\
LR & 0.100 & -0.025 & 0.071 & 0.045 & 0.890 \\
OBSR & 0.413 & 0.600 & 0.032 & -0.011 & -0.823 \\
\hline
\end{tabular}

In order to explain the economic implications of the main factors better and make load value of original variables different significantly, original variables loading matrix can be rotated to factor loading matrix after iterating six times by varimax orthogonal rotation, shown in Table 2 . The factor loading value is different obviously after 
rotating.

F1 includes indicators of IPM, CPR, ROTA, GRNP and PCR, whose loading values are greater than 0.5.Generally, it reflects banks profitability. It is a comprehensive index, and be named the profitability factor.

F2 includes indicators of NIIR, OBSR, NPAR and CAR, whose loading values are greater than 0.5. Generally, it reflects banks innovation capability and assets security. It will affect potential development and security in market, so it can be named as market potential factor.

There is only one index in F3. It is CIR, whose loading value is greater than 0.5. In General, it reflects banks operational costs and is names as operational cost factor.

There are two indices of RCD and RMT in F4, whose loading value is greater than 0.5. This is bank's comprehensive index of human capital, so it is named as human capital factor.

The indices of LDR and LR are in F5. It is comprehensive index of banks asset Liquidity. So it is named as liquidity factor.

The every factor score of respective bank sample is expressed by the variable of Z1, Z2, Z3, Z4 and Z5. And variance contribution rate is used as the weight. So the overall score of every bank's competitiveness can be calculated by the following formula, as in

$$
F=Z 1 \times 38.813 \%+Z 2 \times 23.796 \%+Z 3 \times 11.776 \%+Z 4 \times 8.672 \%+Z 5 \times 5.823 \%) / 88.87 \%
$$

The score of every factor variable from Z1 to Z5 can be calculated and the overall score of banks competitiveness also can be calculated with (1). The sorting of joint stock commercial bank competitiveness can be gotten done based on the overall score. The results are shown in table 3.

Table 3. The scores of variables and sorting for banks competitiveness

\begin{tabular}{lccccccc}
\hline Indicator & Z1 & Z2 & Z3 & Z4 & Z5 & Score of F & Sorting \\
\hline CIB & 0.7939 & -0.5369 & -0.0566 & 0.9847 & -0.6408 & 0.24965 & 6 \\
CMB & 1.0739 & 0.5106 & 0.5840 & 1.7386 & -0.8371 & 0.7979 & 1 \\
CMBC & 0.3642 & -0.0997 & 1.5455 & -0.4085 & -0.4725 & 0.2664 & 5 \\
SPDB & 0.8947 & -2.0087 & 0.1182 & -0.4703 & 1.6218 & -0.0709 & 9 \\
HXB & -0.7352 & 1.0248 & -1.6472 & 0.5716 & 1.2208 & -0.1293 & 10 \\
SDB & -2.4133 & -1.2562 & -0.3875 & 0.7907 & -0.6119 & -1.4047 & 11 \\
CITIC & 0.2705 & 0.0304 & -1.3403 & 0.3986 & 0.7953 & 0.0397 & 8 \\
BOCOM & 1.0003 & 0.3501 & 0.3893 & -0.2612 & -0.5244 & 0.5223 & 3 \\
ICBC & 1.5951 & 1.6025 & -1.179 & -1.4527 & -1.0085 & 0.7615 & 2 \\
BOC & 1.1096 & 0.1105 & -0.8261 & -1.9246 & -1.4974 & 0.1188 & 7 \\
CCB & 0.5649 & 1.2726 & -0.6080 & -0.7291 & -0.0622 & 0.4316 & 4 \\
\hline
\end{tabular}

\subsection{Empirical Result}

\subsubsection{Profitability Factor}

$\mathrm{F} 1$ is the index reflecting banks profitability. Every bank score of this factor is shown in the second column (Z1). The first two are ICBC and BOC, whose scores are 1.5951 and 1.1096 for each. That is in accordance with reality. Both ICBC and BOC are state-owned, so they develop faster and faster. The third is $\mathrm{CMB}$, and then is BOCOM. So at the profitability state-owned bank is the main actor. Other non state-owned banks, such as CMB and CIB, still have potential competitiveness and development.

\subsubsection{Market Potential Factor}

Column three (Z2) is the score of F2. Of those banks the first is still ICBC, whose score is 1.6025. The second is $\mathrm{CCB}$ and the following is $\mathrm{HXB}, \mathrm{CMB}$ and BOCOM. The respective score is $1.2726,1.0248,0.5106$ and 0.3501 . Of the top five banks there three ones are state-owned banks. BOC is only at the sixth status. So at market 
potential perspective, it's still mainly of state-owned banks. They have sufficient operational capital and CAR is higher except the income of non interest and off balance sheet, so they have comparative advantage in potential market development and security. However, most of non state-owned banks are at back for their own lower NIIR and OBSR. With the joint stock banks development, the non state-owned bank will improve the competitiveness step by step.

\subsubsection{Operational Cost Factor}

The score of $\mathrm{F} 3$ is in the column four (Z3). The top five banks of high score are CMBC, CMB, BOCOM, SPDB and $\mathrm{CIB}$, of which there are all non state-owned banks. That means during the operation, they have comparative disadvantage in operational cost compared with state-owned banks. However, HXB, CITIC, CIBC and BOC have lower score, which means they have higher competitiveness on the aspect of operational cost.

\subsubsection{Human Capital Factor}

In the factor of $\mathrm{F} 4$, the non state owned banks have stronger competitiveness than state owned banks. In the column five (Z4), the top five banks are CMB, CIB, SDB, HXB and CITIC, while the four state-owned bank are behind them. That because much more persons with higher education and title are employed in the non state-owned banks during the recent year. The banking industry is knowledge-intensive, so that financial professionals play important roles in enhancing their competitiveness.

\subsubsection{Liquidity Factor}

Column six (Z5) is the score of F5. In this column all of SPDB, HXB, CITIC, CCB and CMBC have the higher score. They are the top five banks at liquidity factor. Except CCB, other three state-owned banks are at back, which means they have weaker liquidity. On the other hands, the banks with higher liquidity will face more risk, so they must strong the risk management and defense.

\subsubsection{Comprehensive Analysis of Competitiveness}

The seventh and last column are the overall score and sorting of all sample banks. From the results, the top two banks are $\mathrm{CMB}$ and ICBC. BOCOM, CCB and CMBC are followed. Although the state-owned banks have comparative competitiveness, the non state-owned banks still show the potential development, especially CMB. In another word, the competitiveness of CMB has been over others including state owned banks.

\section{Conclusion}

To summarize, the indicator system is built up in the paper to analyze the competitiveness of joint stock commercial banks in China utilizing factor analysis method, which consists of seven primary indictors and eighteen secondary indicators. After empirical test, 11 joint stock commercial banks have different competitiveness in the five main factors that are chosen. But from the overall competitiveness, CMB is the top one followed with ICBC. BOCOM, CCB and CMBC. Non state-owned banks have more potential competitiveness than others.

Based above, joint stock commercial banks have good development environment, especially the state-owned banks, owe to the speed economy development and policies. The joint stock commercial banks should centralize on asset activity development and support the innovation of resource relocation. And a sound internal control mechanism should be established to optimize corporate governance structure. They also can adjust the credit flow, strengthen the key business, control the industry risk, and make early warning proposal. And if necessary, organization system, management procedure and business process can be reengineered through the risk management. All of those are helpful for enhancing the competitiveness of joint stock commercial banks.

\section{References}

Beckmann, R. (2007). Profitability of Western European banking systems: panel evidence on structural and cyclical determinants. Deutsche Bundesbank working paper, No. 17.

Cengiz, E., Omar, M., Bora, A., \& Bruno, S. (2012). 7th International Scientific Conference Evaluation of competitive conditions in the PRC banking industry. Lithuania.

Cetorelli, N. (1999). Competitive analysis in banking: appraisal of the methodologies. Economic Perspectives, Q1, 2-15. Retrieved from http://www.chicagofed.org/digital_assets/ publications/economic_perspectives/1999/ep1Q99_1.pdf

Claessens, S., \& Laeven, L. (2004). What drives bank competition? Some international evidence. Journal of Money, Credit and Banking, 36, 563-83. http://dx.doi.org/10.1353/mcb.2004.0044 
HUANG, Lan, \& SHENG, Gensheng. (2002). Design the appraisal indices system of bank competitiveness. Jiangsu Statistics, 6, 27-32.

JIAO, Jinpu. (2002). Comparison of the banking competitiveness in China. Beijing: China Financial Publishing House. (In Chinese)

Khrawish, H. A. (2011). Determinants of commercial banks performance: evidence from Jordan. International Research Journal of Finance and Economics, 81, 147-159.

LI, Yuanxu. (2002). Comparison competitiveness of Chinese state-owned commercial banks and foreign banks. Journal of Financial Research, 3, 56-61.

LU, Yuexiang, \& CAO, Yongdong. (2011). Analysis on competitiveness of Chinese city commercial bank. Statistical Research, 28, 110-112 (in Chinese).

Marcia, M. C., \& Hassan, T. (2004). An overview of commercial banks: performance, regulation, and market value. Review of Financial Economics, 13, 1-5. http://dx.doi.org/10.1016/j.rfe.2003.12.002

Naceur, S. B., \& Goaied M. (2003). The determinants of the Tunisian deposit banks' performance. Applied Financial Economics, 11, 317-319. http://dx.doi.org/10.1080/096031001300138717

Nakane, M. I. (2001). A test of competition in Brazilian banking. Banco Central do Brasil Working Paper No. 12.

SONG, Wenchang. (2007). The comparative research of competitive abilities of public listed commercial banks in China. Journal of Shanxi Finance and Economics University, 3, 94-100.

Toni, U. (2008). Determinants of bank profitability: Macroeconomic evidence from Nigeria, Deakin University working paper. http://dx.doi.org/10.2139/ssrn.1231064

YANG, Jiacai. (2008). Commercial bank competitiveness and its evaluation. Journal of Financial Research, 12, 147-162.

YAO, zheng, \& SHAO, Qinhua. (2005). Index selection for the evaluation of commercial banks' competitiveness and its weight ascertainment. Science \& Technology Progress and Policy, 1, 67-69. 